\title{
Antidemokratik Sistemlerde Siyasi Rejimi Korumaya Yönelik Mekanizmalar ve Bunların Demokratikleşmeyle İlişkisi
}

Hasan Emir AKTAŞ ${ }^{1}$

Özet

Dünyanın diğer bölgelerindeki demokratikleşme eğilimlerinin aksine Orta Doğu ve Asya bölgesinde demokratikleşme süreci oldukça yavaş ilerlemektedir. Bu bölgelerde yer alan ülkelerde, siyasi rejimlerin kendi varlıklarını koruyup konsolide etmelerinde bazı koruyucu mekanizmaların rol oynadığı görülmektedir. Bu mekanizmaların bir kısmı milli bağımsızlığı ve güvenliği koruma gayesi taşısa da büyük bir kısmı, demokratik bir dönüşümü ve sosyal dinamiklere dayalı bir yeniden yapılanmayı engelleyerek, otoriter yapıyı sürdürmeyi amaçlamaktadır.

$\mathrm{Bu}$ çalışmada bahsi geçen bölgelerdeki antidemokratik sistemlerde yer alan rejimi koruyucu mekanizmalar ele alınmaktadır. Daha sonra bu mekanizmalar ayrı ayrı incelenerek, bunların demokratikleşmeyle ilişkileri belirlenmeye çalışılmaktadır.

Kuşkusuz ki büyük gerilimlerin yaşandığı bu bölgelerde, gerilimleri çözebilecek en önemli formül, bu ülkelerde yerli demokratik süreçlerin gelişmeye başlamasıdır. Demokratik süreçlerin gelişme şansını anlamak için de değişimi engelleyen potansiyel mekanizmaları tanımak gerekmektedir.

Anahtar Kelimeler: Orta Doğu, Antidemokratik Rejimler, Koruyucu Mekanizmalar, Demokratikleşme

\section{Protective Mechanisms for Antidemocratıc Regimes and Their Relationship with Democratization}

\begin{abstract}
Unlike other regions, democratization trends are developing slowly in the Middle Eastern and Asian parts of the world. It is seen that in those regions,some protective mechanisms play a role for the political regimes to maintain and consolidate themselves.Although some of these mechanisms aim to protect national independence and security, most of them have the function to maintain the authoritarian structure, hindering a democratic transformation and a reconstruction based on social dynamics.

This paper studies the mechanisms protecting some antidemocratic regimes in those regions. Then, these mechanisms are examined separately, seeking to find out their relationships with democratization.

No doubt, in those countries in which substantial tensions are taking place, the crucial remedy to handle these tensions may be development of the natural democratization processes. And in order to understand the development of democratization processes, we need to recognize the mechanisms which protect these regimes and hinder any potential change.
\end{abstract} Democratization

Key Words: The Middle East, Antidemocratic Regimes, Protective Mechanisms,

${ }^{1}$ Yrd. Doç. Dr., Atatürk Üniversitesi, İ.İ.B.F., Kamu Yönetimi Bölümü, hasanaktas@atauni.edu.tr. 
Yalova Sosyal Bilimler Dergisi

\section{Giriş}

1980 ve 1990'lardan sonra dünyanın birçok bölgesinde bir demokratikleşme dalgası (Huntington'un tabiriyle üçüncü demokrasi dalgası) görülmüştür. Doğu Avrupa'daki eski sosyalist ülkeler, Güney Avrupa'da yer alan askeri diktatörlükler (İspanya ve Yunanistan) ve yine Latin Amerika'daki bazı diktatörlükler bu dönemde demokratik sistemlere geçiş yapmaya başlamışlardır. Fakat birçok uluslararası gerilim ve anlaşmazlığa sahne olan Ortadoğu ve Asya'nın büyük bir bölümü demokratikleşme yönünde kayda değer bir gelişme sağlayamamıştır. Kuşkusuz ki dünyada totaliter ve otoriter sistemler aleyhinde ve demokrasi lehinde genel bir eğilim oluşmasına rağmen, bu bölgelerde demokratikleşme yönünde ciddi bir ilerlemenin kaydedilememiş olmasının iç ve dıştan kaynaklanan birçok sebebi bulunmaktadır.

Fakat bu bölgede meydana gelen gerilim ve krizler, çıkar ve güç çatışmaları büyük yıkımlara, acı ve facialara yol açmaktadır. Büyük güçlerin karışıklık, ayrışma ve çatışmaları tahrik ettiği bir çerçevede bu toplumlardaki yerli unsurların sağduyusunu, ortak aklını, uzlaşma kültürünü devreye sokmaktan başka bir çare gözükmemektedir. Çünkü demokratik olmayan rejimler, bu toplumların bazı unsurlarını dışlayıp yabancılaştırmakta ve bu şekilde nefret ve gerilime sebebiyet vermektedir. Ortaya çıkan nefret ve gerilimler ise marjinal grupların, terörist örgütlerin ve illegal yapılanmaların zuhuruna zemin hazırlamaktadır. Büyük güçlerin ve uluslararası güç sisteminin Ortadoğu'da halka dayalı yönetimlerin kurulmasına yönelik köklü değişimlerin gerçekleşmesi noktasında çok iyi niyetli olmadığı anlaşılmaktadır. Mesela ABD Mısır'da demokratik bir dönüşümü darbeye destek olarak engellemiştir. Rusya stratejik çıkarlarını korumak için Suriye'deki demokratik bir dönüşümü engellemiş ve bu şekilde yüz binlerce insanın ölümüne zemin hazırlamıştır.

Arap toplumları "Arap Baharında" onlarca yıldır yaşadıkları otoriter ve tek tipçi yönetimlerin baskılarına karşı kendi hürriyetini, refahını ve geleceğini kurtarmak adına her şeyi göze alarak bir mücadeleye girişmiş, fakat dışarıda emperyalist güçler ve içerde kurulu düzen unsurları bütün vasıtalarıyla bu halk hareketlerine diz çöktürmeyi başarmıştır. Fakat demokratik bir dönüşüm, bu toplumların potansiyelini devreye sokabilecek ve sosyal dinamiklerini istikrarlı bir yapıya kavuşturacak tek çözüm olduğuna göre, bu gayeyi aramaktan ve takip etmekten başka bir yol yoktur.

Bu çalışmada ilk olarak Ortadoğu ve Asya'daki önemli bazı antidemokratik sistemlerde rejimi koruyucu mekanizmalar, ülkeler bazında değerlendirilecektir. Sonraki bölümde ise elde edilen bilgiler çerçevesinde bu mekanizmalar ayrı birer kategorik faktör olarak ele alınacaktır. Bu mekanizmaların bir kısmı bağımsızlığı ve ülke bütünlügünü korumak amacını taşısa da bunların çoğunun, antidemokratik sistemi, değişim taleplerine ve toplumsal dinamiklerin baskısına karşı koruma işlevi gördükleri muhakkaktır. Bu sebeple bu sistemleri dönüştürmeye yönelik bir çaba için öncelikle onları koruyan mekanizmaları tanıyıp teşhis etmek gerekmektedir.

Mısır, Irak gibi ülkeler bölgenin önemli ülkeleri olmakla birlikte son y1llardaki kırılmalardan sonra şu an itibariyle bu ülkelerde yerleşmiş bir kurumsal yapı henüz oluşmadığı için ülkeler bazındaki değerlendirmeye alınmamıştır. Fakat bu ülkelerin 
Yalova Sosyal Bilimler Dergisi

siyasi tarihlerinde yer alan bazı uygulamalara da yeri geldikçe örnek mahiyetinde değinilecektir.

Diğer taraftan Türk siyasi sistemi çeşitli demokratik kurumları ișletmesi bakımından bölgedeki diğer ülkelerden farklılık arz etse de son beş yıla kadar askeri vesayetin sistem üzerinde derin bir kontrol icra ettiği bir gerçektir. İkinci olarak Kemalist ideolojiyi dogmatik bir bağlllıkla benimseyen elitlerin askeri ve sivil bürokrasideki hâkimiyetleri, farklı kimlik ve görüşteki kesimlerin siyasi zeminde temsilini, diğer bir ifadeyle çoğulcu demokrasiyi ciddi şekilde kısıtlamıştır. Fakat son beş yılda bu vesayetin kırılmaya başlaması ve Kemalist ideolojinin siyasi yapının üzerine attığı ağır perdenin hafiflemeye başlaması, üretici Türk sosyal dinamiklerine bir potansiyel ve Türk siyasetine bir hareket kabiliyeti olarak yansımaya başlamıştır.

\section{Antidemokratik Bazı Rejimlerde Koruyucu Mekanizmalar}

\section{1. İran}

İran Ortadoğu'nun en önemli ülkelerinden birisidir. Nüfus potansiyeli, petrol üretip ihraç eden ülkeler içerisindeki ağırlığı ve bunun neticesinde sahip olduğu ekonomik potansiyel, dünyadaki iki yüz milyona yakın Şii nüfusun en yoğun olduğu ülke olması ve bu Şii nüfusu uluslararası arenada temsil etme çabaları ve nihayet eski Fars devlet geleneğinin varisi olarak Ortadoğu'da ve dünyada önemli bir aktör olma emelleri İran'ı Ortadoğu'daki dengeler açısından önemli bir ülke haline getiren bazı sebeplerdir. İran, Suudi Arabistan, Mısır, Türkiye ve İsrail ile birlikte Ortadoğu'nun modern siyasi tarihinde ve bugünkü gelişiminde en önemli aktörlerden birini oluşturmaktadır. Şu anki İan devletinin zaman saman saldırgan ve emperyalist politikalarla farklı ülkelerdeki Şii dinamiklerini de devreye sokarak Ortadoğu'daki dengeleri sarsabilecek bir potansiyel ve stratejiye sahip olması, İran'ın kendi iç dinamiklerine dayalı olarak, daha demokratik, şeffaf, rasyonel ve uzlaşılabilir bir devlet haline gelmesinin hem kendi halkı ve hem de bölge için önemini ortaya koymaktadır.

\subsubsection{Dini Rehberlik}

İran Anayasası'nın 110. Maddesi Dini Lideri oldukça geniş ve belirleyici yetkilerle donatmıştır. Bu yetkiler şunlardır: 1. Maslahat Konseyi ile istişare ettikten sonra İran İslam Cumhuriyetinin umumi politikalarını belirlemek. 2. Sistemin umumi politikalarının uygun şekilde icra edilip edilmediğini denetlemek. 3. Milli referandumların yapılması için kararname çıkarmak. 4. Silahlı kuvvetlerin başkomutanlığını üstlenmek. 5. Savaş ve barış ilanına karar vermek ve silahlı kuvvetleri seferber etmek. 6. Koruyucular Konseyinin İslam hukukçusu üyelerini; yüksek yargı başkanını; İran radyo ve televizyon teşkilatının başkanını; genelkurmay başkanını; Devrim Muhafizları Ordusunun başkomutanını ve silahlı kuvvetlerin üst düzey komutanlarını atamak, görevden almak ve bunların istifasını kabul etmek. 7. 
Silahlı kuvvetlerin üç kolu arasındaki anlaşmazlıkları çözüme bağlamak ve bunlar arasında koordinasyon sağlamak. 8. Cumhurbaşkanının halk tarafından seçilmesine resmiyet kazandıran kararnameyi imzalamak. 9. Birinci dönem için Cumhurbaşkanlığı seçimine katılan adayların Anayasada belirtilen vasıflara uygun olup olmadığını teyit etmek. (İkinci dönem için yarışanları sadece Koruyucular Konseyi denetlemektedir). 10. Yüksek Mahkemenin anayasal görevlerini ihlal etmekten suçlu bulması veya Milli Meclisin yaptığı oylama sonucunda görevlerini yapamadığı yönünde karar alması üzerine Cumhurbaşkanını görevden azletmek.

Görüldüğü gibi İran'da Dini Liderin görevlerinden, ülkenin genel politikalarını belirlemek, referandumlara karar vermek, silahlı kuvvetlerin başkomutanlığını üstlenmek gibi bazıları, başkanlık sisteminde başkanın veya yarı başkanlık sisteminde cumhurbaşkanının yetkilerine tekabül etmektedir. Aslında Dini Liderin tek seferde, dolaylı ve kısıtlı bir mekanizma ile seçilmesi ve hayat boyu bu görevde kalabilmesi bahsettiğimiz bu türden yetkileri kullanması için gerekli olan demokratik temelden de yoksun olduğunu göstermektedir. Fakat diğer bazı görevleri var ki sistemin bütün kritik noktalarını ve temel mekanizmalarını Dini Liderin kontrolüne bağlamaktadır. Demokratik sistemlerde bu yetkiler ya kuvvetler ayrımı çerçevesinde, milli meclis, yargı erki gibi farklı organlara veya doğrudan halkın iradesine bırakılmaktadır. Mesela Cumhurbaşkanının hem adaylığının kabulü, hem de eğer seçilmişse göreve başlamasına resmiyet kazandırılması, Dini Liderin yetkisi dâhilindedir. Silahlı kuvvetlerin bütün unsurlarının yönetim ve komuta kademesi, sıkı şekilde Dini Liderin kontrolü altındadır. Radyo ve televizyonu denetleyecek kurumun başkanı Dini Lider tarafından belirlenmektedir. Koruyucular Konseyine atadığı "fakihler" vasıtasıyla milletvekili adaylarını yine sıkı şekilde denetleyebilmektedir.

Dolayısıyla İran'daki siyasi sisteme bakıldığında sistemde değişiklik yapabilecek, muhalif unsurlar üretebilecek bütün mekanizmalar ve kanallar, kaynağından Dini Lidere bağlanmış bulunmaktadır. Mesela dünyadaki farklı ülkelerin siyasi tecrübelerine bakıldığı zaman, siyasi farklılığa ve çoğulculuğa, muhalif çıkışlara, değişim taleplerine veya sistemi değiştirme teşebbüslerine zemin hazırlayan en önemli mekanizmalar milletvekilliği ve başkanlık gibi seçime dayalı kurumlar, ifade hürriyetini kullanabilen iletişim araçları, farklı veya muhalif eğilimler taşıyan ordu birlikleri, hukuki standartları hayata geçirmek isteyen bağımsız yargı ve bilhassa anayasa yargısıdır. İște İran'da siyasi sistemde değişiklik doğurabilecek ve muhalif hareketlenmelere yol açabilecek bütün kurum, organ ve mekanizmalar demokratik denetim araçlarından muaf olan Dini Liderliğin mutlak yetkileriyle koruma altına alınmaya çalışılmıştır.

\subsubsection{Koruyucular Konseyi (Şura-yı Nigehban)}

İran Anayasasında Koruyucular Konseyinin amaç ve görevleri ile teşekkül biçimi şu şekilde düzenlenmektedir: 
“İslami hükümleri ve Anayasayı muhafaza etme gayesiyle, İslami Danışma Meclisinin (Parlamento) çıkardığı yasaların İslam'a uygunluğunu denetlemek üzere Koruyucular Konseyi adında bir konsey kurulacaktır. Bu konseyin teşekkülü ise şu şekilde olacaktır:

1. (Dini) Lider tarafindan seçilecek olan, mevcut ihtiyaçlara ve günün meselelerine vakıf altı din hukukçusu,

2. Yüksek Yargı Başkanı tarafından aday gösterilen Müslüman hukukçular arasından İslami Danışma Meclisi tarafından seçilecek olan hukukun farklı alanlarında uzmanlaşmış altı hukukçu" (İran Anayasası, 91. Madde).

İran Anayasasının 93. Maddesinde Koruyucular Konseyi olmadan İslami Danışma Meclisinin (yani yasama organının) yasama yetkisinin hiçbir hükmünün olmadığını belirtilmektedir. Anayasanın 94. Maddesi Koruyucular Konseyi'nin yasama sürecindeki rolünü şu şekilde düzenlemektedir: "İslami Danışma Meclisinden geçirilen bütün yasa tasarıları Koruyucular Konseyi'ne gönderilecek, Konsey de on gün içerisinde gönderilen yasa taslağının Anayasaya ve İslami kıstaslara uygun olup olmadığını denetleyecektir. Eğer uygun değilse yeniden görüşülmek üzere Meclise geri gönderecektir; eğer uygunsa yasa yürürlüğe girmiş olacaktır”.

İran Anayasasının 96. Maddesine göre, Meclis’ten gelen yasa tasarılarının İslam'ın hükümlerine uygunluğu sadece Dini Liderin atadığı altı din hukukçusunun çoğunluk kararına göre belirlenecek; bu tasarıların Anayasaya uygunluğu ise bütün üyelerin çoğunluk kararı ile belirlenecektir. Anayasanın 98. Maddesine göre Anayasayı yorumlama yetkisi Koruyucular Konseyi'ne aittir. Bu yetki Konsey üyelerinin dörtte üçünün kararı ile gerçekleşecektir.

Anayasa'nın 99. Maddesine göre, Koruyucular Konseyi, Liderlik Uzmanlar Konseyi, Cumhurbaşkanlığı ve İslami Danışma Meclisi için yapılan seçimler ile halkoylamaları ve referandumların denetlenmesinden sorumludur.

Konsey'in Anayasada belirtilen görev ve yetkilerinin dışında ayrı bir yasayla verilmiş başka yetkileri de bulunuyor: Konsey cumhurbaşkanlığ ve milletvekilliği gibi seçime dayalı makamların bütün adaylarını denetleme yetkisine sahip (Kesselman vd. 2009: 399).

2000 ve 2004 seçimlerinde konsey "İslam'a karşı saygılı olmadığına" hükmettiği birçok aday adayının adaylığını reddetmek suretiyle aday listelerinin oluşumunu ciddi biçimde etkilemiştir. Diğer taraftan bu organ, 21. yüzyılın ilk beş yılında Meclisin kabul ettiği yasa tasarılarının yaklaşık üçte birini veto etmiştir (Alaedini vd., 2006: 622).

Eğer Konsey üyelerinin çoğunluğu, önüne gelen yasa tasarısını kabul ederse, tasarı resmiyet kazanmaktadır. Konseyin onayını almayan bir tasarı veto edilmiş olmaktadır. Siyasi sistemde veya sosyal yapıda reform yapmayı amaçlayan tasarılar bu şekilde engellenmiş olmaktadır. Meclis ile Konsey arasındaki ihtilafları çözmek için 
Yalova Sosyal Bilimler Dergisi

Dini Lider tarafından tayin edilen "Çözüm Konseyi" ise başka bir yasama organı durumundadır (Roskin, 2014: 685).

Konsey'in yapısına ve kuruluş amaçlarına bakıldığında, bu mekanizma ile İran siyasi sisteminin temelini teşkil eden üç unsurun korunmaya çalışıldığ görülmektedir: Bunlardan birincisi yasa tasarılarının ve seçime dayalı yasama ve yürütme pozisyonlarına aday olan kişilerin İran sisteminin ideolojisi olan On İki İmam Şiiliği çerçevesindeki İslam hukukuna uygun olup olmadığının denetlenmesidir. Konsey üyelerinin altısının yani yarısının din hukukçusu olması doğrudan bununla ilgilidir. Korunmak istenen ikinci unsur mevcut anayasal yapı ve Dini Liderin şekillendirdiği üst düzey devlet örgütünün muhafazasıdır. Üyelerin yarısının bizzat Dini Lider tarafindan atanması ve Meclis ile Konsey arasında anlaşmazlık olması durumunda devreye giren "Çözüm Konseyi"nin de doğrudan Lider tarafından tayin edilmesi, kurulu devlet örgütünü koruma çabasının bir tezahürüdür.

Konseyin yetki ve kararlarıyla korunmak istenen üçüncü unsur da mevcut sosyo-ekonomik yapıdır. İslam devriminin getirdiği yeni siyasi düzenle sosyoekonomik yapıda bazı değişiklikler gerçekleşmiş olmakla beraber, bu alanda radikal değişikliklerin yapılmasına mevcut siyasi sistem izin vermemektedir. Mesela Şah döneminde aşırı zenginleşmiş kesimler bir ölçüde kontrol altına alınmakla birlikte, sosyalist tarzda bir devletleştirmeye veya orta sınıfı oluşturan esnaf ve toprak sahiplerinin mülkiyet hakkının iptal edilmesine karşı Konsey dengeleyici bir işlev görmektedir. Konsey üyelerinin yarısının çeşitli hukuk dallarındaki uzman kişilerden oluşması ve bunların Milli Meclis ile Yüksek Yarg1 Başkanı tarafından müştereken belirlenmesi, sosyo-ekonomik yapıdaki dengeyi sürdürme çabası olarak göze çarpmaktadır. Nitekim Konsey'in geri çevirdiği yasa tasarıları arasında toprak reformu ve kamulaştırma amaçlayan tasarılar önemli bir yer tutmaktadır.

\subsubsection{Devrim Muhafizları}

İran'da resmi ordu kurumlarının dışında ayrı bir silahlı yapılanma olarak oluşturulan Devrim Muhafızları ilk kurulduğu zaman, devrilen Şah'a bağlı olabileceği düşünülen ordu, polis ve jandarma kuvvetlerini dengelemek, Halkın Mücahitleri gibi solcu grupları kontrol altına almak ve İslam devriminin siyasi ve dini ideolojisini desteklemek amacına yönelikti. Daha sonraki süreçte gittikçe genişleyen ve güçlenen bu yap1, muhalif Kürt güçleriyle mücadele etme ve İran-Irak Savaşında ordunun yanında savaşma gibi işlevler için devreye sokulmuştur. Bu yapı ayrıca, iç güvenliği temin ve maneviyatı takviye için de kullanılmaktadır (Seddon, 2005: 580).

İran Anayasasının 150. Maddesine göre Devrim Muhafizları Ordusunun İslam Devrimini ve onun başarılarını koruma rolü devam edecektir. Devrim Muhafızlarının bilhassa Lübnan, Irak gibi Şii nüfusa sahip ülkelerde devrimi ihraç etme, müttefik unsurları destekleme gibi yayılmacı ve müdahaleci bir politikanın aracı olma gibi bir görevi de bulunmaktadır. Nitekim Suriye'deki iç savaşta da Devrim Muhafızlarının Suriye rejiminin yanında aktif bir rol üstlendiği görülmektedir. Devrim Muhafızları 
doğrudan dini lidere bağlı bir yapı olarak, otoriter rejime ve mutlak yetkilerle donatılmış olan dini lidere yönelik her türlü muhalif hareketi etkisiz hale getirme noktasında birinci derecede fonksiyonu olan silahlı bir kuvvettir.

\section{2. Çin}

Çin Uzak Doğu'nun ve dünyanın en önemli ülkelerinden biridir. Dünyanın en büyük üretken nüfus potansiyeline sahip olması, yakaladığı ekonomik büyüme trendiyle dünyanın en büyük ikinci ekonomisi olma başarısı, büyük endüstriyel kalkınma seviyesi ve teknolojik kapasitesi, Soğuk Savaş döneminden beri bağımsız bir uluslararası güç merkezi olma hedef ve stratejisi ve bu bağlamda yakın ve uzak bölgelerde nüfuz alanı oluşturma teşebbüsleri Çin'i bölgesi ve dünya için önemli bir ülke haline getirmektedir. Çin uluslararası politikaları yönlendirme bakımından bugüne kadar, sahip olduğu potansiyeli tam olarak kuvveden fiile geçirmiş değildir. Fakat hem ileri düzeydeki sanayi ve teknoloji kapasitesi, hem de otoriter ve merkezileşmiş komünist devlet yapısı büyük ve riskli bir güç birikmesini ifade etmektedir. $\mathrm{Bu}$ bakımdan Çin siyasi sisteminin daha demokratik ve rasyonel bir çerçevede dönüşmesi bölge ve dünya barışı açısından daha yapıcı ve uzlaşmacı bir devlet olmasında yararlı bir faktör olabilir.

\subsubsection{Komünist Parti}

Sovyetler Birliğinde ve bu modeli izleyen birçok Komünist ülkede olduğu gibi Çin'de de siyasi sistemin merkezinde Komünist Parti ideolojisi, teşkilatı ve yönetimi yer almaktadır. Komünist Parti ülkenin merkezinde ve taşrada yapılanan devlet örgütlenmesine paralel şekilde örgütlenmektedir. Dolayısıyla üst düzey devlet görevlerine gelebilmek için mutlaka parti hiyerarşisi içerisinde yükselmiş olmak gerekmektedir. Yani ideolojik ve totaliter bir devlet sistemi uygulayan Çin'de siyasi, idari ve yasama alanında atılan adımların bu ideolojik değer ve standartlara uygunluğunu denetleyen başlıca mekanizma Çin Komünist Partisi yönetim kadroları olmaktadır.

Mesela Komünist Partinin en üst düzey organı kabul edilen Milli Parti Kongresinin üyelerinin çoğu üst kanat yasama organı olan Milli Halk Kongresinin üyesidir. Yine mesela Çin siyasetinin üst düzey makamlarında görev alan bir lider, önce Parti'nin yüksek pozisyonlarına tırmanır, daha sonra devletteki görevini üstlenir. Nitekim Çin'in önceki devlet başkanı olan Hu Jintao başkan olarak atanmadan önce, bir sure Komünist Parti genel sekreterliği yapmıştır (Roskin, 2014: 521).

Sovyetler Birliğinin çöktüğü 1990'lı yıllardan itibaren Komünist Partinin nüfuz ve etkinliği biraz zayıflamakla birlikte, halen ülkenin en güçlü ve etkili siyasi organı olmaya devam etmektedir (Parlak ve Caner, 2013: 263).

Bu noktada Çin'i mesela yine bir ideolojik devlet olan İran ile karşılaştırırsak, İan'da milletvekili veya cumhurbaşkanı olabilmek için doğrudan halkın karşısına 
Yalova Sosyal Bilimler Dergisi

çıkılmakta ve seçmenlerin çoğunluk oyunu almak gerekmektedir. Dolayısıyla bu makamlara ideolojik kurulu düzenin dışından birilerinin aday olabilme ve halkın oyunu alabilme imkânı teorik olarak bulunmaktadır. Bu sebeple de sistem kurulu düzenin kabul etmeyeceği adayların seçim yarışına katılımını önleyebilmek için Koruyucular Konseyi gibi ilave mekanizmalara ihtiyaç duymuştur. Hâlbuki Çin'de adaylar yasamanın ve yürütmenin ve hatta bürokrasinin üst makamlarına gelmeden önce Partinin birçok kademesinde denetlenmekte ve ideolojinin ve kurulu düzenin kriterlerine göre elemeye tabi tutulmaktadır. İşte siyasi yükselme kanallarının denetimi bu şekilde sağlandıktan sonra, halk kesimlerinden kaynaklanabilecek karışıklık ve kaos tehlikesine karşı da ordu devreye girmek suretiyle sistemi korumaktadır.

\subsubsection{Ordu ve Güvenlik Kuvvetleri}

Sovyetler Birliği'nin aksine Çin'de ordunun da iktidarı ele geçirmek için değil de ülkeyi düzensizlik ve çöküşten kurtarmak için bariz şekilde siyasete müdahale ettiği görülmektedir (Roskin, 2014: 521).

Çin ordusu Merkezi Askeri Komisyon ile Çin Komünist Partisine bağlanmaktadır. Çin Komünist Partisi Merkez Komitesinin belirlediği Merkezi Askeri Komisyon, ülkedeki bütün silahlı kuvvetlere doğrudan komuta etmektedir. Merkezi Askeri Komisyon aynı isim ve üye yapısıyla aynı zamanda devletin bir kurumunu da teşkil etmektedir (Batmaz, 2015: 412-413). Bu şekilde Komünist Parti karar ve yönetim organı olan Merkez Komitesi, Halkın Kurtuluş Ordusu üzerinde kontrol kurmakta ve onu Komünist rejimi koruyup güçlendirmek için bir araç olarak kullanmaktadır.

\subsection{Türkiye}

Türkiye Cumhuriyetinin bir taraftan Batılı standartlarda demokratik bir sistem kurmaya çalışırken, diğer taraftan bu standartlar içerisinde pek de karş1lığı olmayan Kemalizm adındaki resmi ideolojik yapıyı inşa ettiği görülmektedir. Elbette Kemalizm'in ana ilkeleri Batı siyasi tecrübelerinden mülhemdi. Fakat Batıdan alınan bu ilke ve fikirler, yeni Türkiye devletinin kurucularının ve reformcu kadronun kendi bakış açılarına, değer yargılarına ve ulaşmak istedikleri modele göre yeniden şekillendirilmişti. Bu model laiklik, modernleşme, milliyetçilik gibi konularda mesela Fransız modeliyle yakın bir benzerlik arz etse de demokratik birçok Batı sistemine pek de benzemiyordu. Kemalist modelde laiklik, Atatürkçülük, milliyetçilik gibi bazı kavramlar adeta kutsallaştırılıyor ve ideolojik devletlerde olduğu gibi dokunulmazlık k1lıfları içerisinde korunmaya çalış1lıyordu. Hâlbuki çağdaş ve demokratik Batı toplumlarının genel standartlarına bakıldığı zaman korunmaya çalışılan değerlerin, halkın çoğunluğunun, diğer bir ifadeyle ortalama bir sivil ve demokrat vatandaşın mantığıyla ve rasyonel bakışıyla kabul edebileceği prensip ve değerler olmaktadır: Temel insan haklarının korunması, inanç hürriyetinin sağlanması, hukukun üstünlüğünün tesisi gibi. 
Resmi ideolojide yer alan bazı ilkelerin kutsallaştırılması, siyasi ve kültürel reformların sosyolojik dinamiklerin doğal sonucu olarak ve zamana yayılarak değil de nispeten kısa süreler içerisinde ve yukardan aşağı doğru empoze edilerek gerçekleştirilmesi ve siyasi sistemin Batı'daki tecrübelerin aksine esas itibariyle halkın kabulüne ve takdirine bağlı bir meşruiyet temeline dayanmaması, modern Türkiye devletinin resmi ideolojisini ve siyasi rejimini korumak için farklı mekanizmaları devreye sokmasına veya demokratik bazı mekanizmalara antidemokratik bazı işlevler yüklemesine sebep olmuştur. Son on beş yılda sistemin daha demokratik bazı standartlar çerçevesinde dönüştürülmesi için önemli bazı reformlar yapılmış olmakla birlikte, Türkiye devletinin ideolojik karakteri birçok alanda varlığını sürdürmektedir.

Türkiye devletinin antidemokratik uygulamalarıyla birlikte siyasi rejimini, resmi ideolojisini ve anayasal düzenini korumak için teşkil ettiği belli başlı mekanizmalar şunlardır:

\subsubsection{Milli Güvenlik Kurulu ve Askeri Vesayet}

1961 Anayasasında Milli Güvenlik Kuruluna yer verilmesiyle askeri bürokrasinin sivil alandaki rolü anayasal düzeyde resmileştirilmiş olmaktadır. Anayasa Kurul'un görev alanını iç ve dış güvenlikle ilgili konularda hükümete tavsiyelerde bulunmak olarak belirlese de sonraki dönemlerde bu yapı hükümet politikası üzerindeki etkisini genişletmiş ve rejimin koruyuculuğu rolünü üstlenmeye başlamış ve bazen gerçek siyasi güç ve karar alma merkezi olarak sivil hükümetin yerini almıştır (Zürcher, 2003: 245).

Aslında Türk siyasi hayatında askeri bürokrasinin bu hâkim rolü, Osmanlı'nın son dönemlerindeki modernleşme reformlarına kadar gitmektedir. Tanzimat döneminde başlayan bürokratik merkezileşme ve askeri modernizasyon süreci merkez çevre ayrımını belirginleştirmiştir. Daha sonra Jön Türk hareketi ve İttihat ve Terakki iktidarı merkezin diğer unsurlarıyla birlikte askerin rolünü güçlendirmiş ve "devletin çıkarlarını" gözetme iddiasında, iktidarı sahiplenen veya en azından ona ortak olmak isteyen bir askeri odak meydana getirmiştir (Mardin, 1973). Cumhuriyetin kuruluşundan sonra askeri bürokrasi yeni rejimin resmi ideolojisi çerçevesinde daha seküler ve modernist bir istikamette indoktrine edilmiştir. 1950'den sonra ise Şerif Mardin'in kavramlaştırmasıyla "çevreye" yaklaşmaya çalışan hükümetlerin ortaya çıkmasıyla, merkezin değer ve doktrinleri çerçevesinde devletin çıkarlarını temsil ettiği iddiasında olan askeri odağın müdahaleci tavrı çok daha bariz hale gelmeye başlamıştır.

\subsubsection{Askeri Darbeler ve Darbe Sonrası Yönetim Mekanizmaları}

Türkiye'de iki açık darbe, birkaç muhtıra, bir postmodern darbe ve birkaç başarısız darbe girişimi olmuştur. Türkiye'deki iç dinamiklerden veya dış güçlerden kaynaklanan bu darbeler ekonomik, güvenlik, istikrar, rejimi koruma veya belli 
Yalova Sosyal Bilimler Dergisi

sınıfların sosyal veya ekonomik çıkarlarını garantiye alma gibi kaygılarla yapılmıştır. Fakat hangi gerekçeye dayanırsa dayansın, darbelerin birçoğunda kurulu düzeni şiddet yoluyla yeniden tesis etme amaç ve çabası görülmektedir. Mesela 1960 darbesi ideolojik ve ekonomik olarak pozisyonlarını kaybetmeye başlayan sivil ve askeri bürokrasinin diğer bazı modernist sosyal unsurları da arkasına alarak gerçekleştirdiği eski düzeni yeniden tesis etme girişimidir (Karpat, 2015: 192-193). Yeni Anayasa'da bazı özgürlükçü maddelerin ve yeni bazı siyasi ve hukuki kurumların yer alması daha çok eski kadroyu antidemokratik şekilde tasfiye eden darbeye ve darbecilere meşruiyet kazandırmak ve siyasi gücü farklı unsurlar arasında dağıtarak çoğunluk halkın iradesini yansıtan hükümetin ve milli meclisin gücünü zayıflatmaktı. Sonuç olarak 1950 öncesindeki kurulu düzen yeniden hâkim duruma getirilmiş oluyordu.

1960 darbesinden sonra kurulan Milli Birlik Komitesi ve 1980 darbesinden sonra kurulan Milli Güvenlik Konseyi sivil yönetime geçilinceye kadar darbenin amaçlarının gerçekleşip gerçekleşmediğine nezaret etmiş ve bir vesayet odağı olarak eski düzenin tam olarak yeniden tesis edilmesini temin ve takip etmiştir.

\subsubsection{Anayasa Mahkemesi}

Anayasa Mahkemesi "bazı kararlarında Atatürk ilke ve inkılaplarını ölçü norm olarak kullandığı, hatta bunları Anayasa kurallarından da üstün tuttuğu izlenimini uyandıran ifadelere yer vermiştir". Mahkemenin Atatürk ilke ve inkılaplarını geniş anlamıyla, yani Atatürkçülüğün bütün ilkeleriyle birlikte Atatürk döneminde gerçekleştirilen bütün reform ve devrimleri içine alacak şekilde bir ölçü norm olarak değerlendirmesi, Türkiye Cumhuriyetine liberal demokratik niteliği ile uyuşmayacak resmi bir ideoloji atfedilmesi anlamına gelmektedir (Özbudun, 1995: 358).

Anayasa Mahkemesi geçmiş dönemdeki bazı kararlarında laikliği çok katı bir çerçevede yorumlamış, Atatürk ilke ve inkılâplarını bütün unsurlarıyla birlikte temel ve üstün bir referans olarak değerlendirmiş ve kendisini kanun koyucunun ve siyasi iradenin tasarruflarına karşı resmi ideolojiyi ve siyasi rejimi koruyan bir pozisyonda telakki ederek tavırlar almıştır. Mesela Mahkeme üniversitelerde başörtüsünün serbest kılınmasına yönelik düzenlemeleri 1989 ve 1990 tarihlerinde laikliğe aykırı olduğu gerekçesiyle iptal etmiştir. Yine üniversitelerle birlikte kamuda başörtüsü serbestisinin sağlanmasına yönelik ve mecliste belli bir mutabakatla çıkarılan bir kanunu 2008'de CHP'nin başvurusu üzerine iptal etmiştir.

Diğer taraftan Anayasa Mahkemesi Yüce Divan sifatıyla parti kapatma davalarına katılmıştır. Refah Partisi, Fazilet Partisi gibi partiler, evrensel demokratik standartlarda karşıllı̆ı olan teröre veya şiddete bulaşma gibi bir delil ve gerekçe olmadığı halde, "laiklik karşıtı eylemlerin odağı olma" gibi oldukça sübjektif ve ideolojik gerekçelerle kapatılmış ve aynı gerekçeyle geniş bir seçmen desteğiyle iktidara gelmiş olan bir partinin (AKP) aleyhinde ekonomik yaptırım uygulanmasına karar verilmiştir. 
Yalova Sosyal Bilimler Dergisi

Siyasi tarihinde yaşadığı birçok antidemokratik uygulamalara rağmen Türk siyasi sisteminin gittikçe daha demokratik bir istikamete doğru ilerliyor olması, bir taraftan Türkiye'deki demokratik kurumlaşmanın daha uzun bir tecrübe sürecinde olgunlaşmaya başlamasıyla, diğer taraftan da demokratik seçimlerin düzenli şekilde uygulanıyor olmasıyla yakından ilişkilidir.

\subsection{Suudi Arabistan}

Suudi Arabistan petrol ihraç eden ülkeler içerisindeki ağırlığı ve bunun neticesinde sahip olduğu ekonomik potansiyel, bölgedeki krallıklar üzerindeki siyasi etkisi, Körfez ülkelerinin Batı bloğuyla ittifakını yönlendiren bir ülke olması, kutsal Hicaz topraklarının yönetimini elinde tutması ve Ortadoğu'daki otoriter sistemleri ekonomik, askeri ve siyasi olarak destekleyici ilişkilere girmesi Suudi Arabistan'ın bölge için önemli bir ülke olduğunu ortaya koymaktadır. Suudi Arabistan'ın siyasi kurumlarında meydana gelebilecek demokratik bir dönüşüm bölgede bir domino etkisi yapabilir ve bölge ülkelerinin sosyal dinamiklerinin, çok daha etkin ve etkili şekilde devreye girmesini sağlayabilir. Diğer taraftan halka dayalı ve tabii bir şekilde gelişen bir demokratikleşme süreci aynı zamanda bölge ülkelerinin büyük güçlerin sömürü ve hegemonya oyunlarına alet olma potansiyelini ortadan kaldırarak, bölgenin problemlerine daha rasyonel, kararlı, gerçekçi ve milli çözümler üretilmesine imkân sağlayacaktır.

Suudi Arabistan, diğer bazı Körfez ülkeleriyle birlikte (meşruti değil) mutlak monarşiyle yönetilen bir ülkedir. Yirminci yüzyılla birlikte dünyada mutlak monarşiler kaybolurken, körfez ülkelerinde bu yapıların devam etmesi, çeşitli şekillerde tartışılan bir meseledir. $\mathrm{Bu}$ ülkelerde demokratik kurum ve uygulamaların yerleşmesinin gecikmesi çeşitli sebeplerle açıklanmaktadır. $\mathrm{Bu}$ sebeplerden birisi geniş petrol gelirlerinin muhalif hareketlerin toplumsal katmanlarda kökleşmesini önleyecek biçimde, halk kesimlerine dağıtılmasıdır. Bu şekilde refah seviyesi yükselen kesimlerin demokratik ve siyasi haklarına yönelik talepleri etkisiz hale getirilmiş olmaktadır. Kuşkusuz ki Suudi Arabistan'da siyasi rejimin korunmasını sağlayan diğer önemli bir faktör de üst düzey hemen bütün siyasi ve idari görevlerin Suudi hanedan üyeleri tarafından üstlenilerek devlet aygıtının kontrol altında tutulmasıdır.

\subsubsection{Hanedan Üyeleri Etrafında Örgütlenen Siyasi ve İdari Yapı}

Suudi Arabistan siyasi sisteminde hâkimiyet Suudi ailesine aittir ve Kralın meşruiyeti ve yetkisi bu ailenin desteğini ve onayını almış olmasına bağlıdır. Kralın halefini (veliahd prensi) belirleme yetkisi de büyük ölçüde (erkek) hanedan üyelerinin rızasına ve hanedan içerisindeki dengelerin sağlanmasına bağlıdır. Hükümetin orta ve üst seviyedeki kritik pozisyonları Suudi hanedanının üyeleri tarafindan üstlenilmektedir. Krallığın kurucusu olan Abdülaziz'in soyundan gelen ve sayıları şuan binleri bulan prensler kilit bakanlıkları, birçok bakan yardımcılıklarını ve 13 bölge valiliğinin çoğunu kontrol altında tutmaktadır (Faksh, 2006: 1167-1168). 
Yalova Sosyal Bilimler Dergisi

Suudi Arabistan siyasi sisteminin uyguladığı, hanedan üyelerinin sadakat, dayanışma ve desteğine dayanan bu yapı, bize İbn-i Haldun'un siyasi düşüncesindeki "asabiyet" kavramını hatırlatmaktadır. İbn-i Haldun'un siyasi yönetimin, kabile veya sülale dinamikleri tarafından desteklenmesi anlamında kullandığı bu kavrama, kabile kültürünün derin izler bıraktığı Ortadoğu ve bilhassa Arap toplumlarında rastlanabilmektedir. Suudi Arabistan gibi monarşik bir sistemde de, Suriye, Saddam dönemi Irak gibi merkeziyetçi ve militarist siyasi sistemlerde de bu yapıyı görmek mümkündür.

\subsubsection{Din Kurumu}

Suud ailesi İslam'ın katı bir mezhebi olan Vehhabilik çerçevesindeki din kurumuna bağlı olduğu ve onu koruyup kolladığı görüntüsü vererek iktidar tekelini meşrulaştırmaya çalışmıştır. Suud rejimi 1960'lardan sonraki hızlı ekonomik ve sosyal değişim döneminde dahi meşrulaştırıcı bir unsur olarak din kurumuna dayanmayı sürdürmüş ve devletin din uleması ile karşılıklı faydaya dayanan ilişkisi devam ettirilmiştir. İbn-i Suud ulemayı devlet hiyerarşisine bağlamış ve ulema da eğitim, hukuk sistemi ve kamu ahlakı alanlarını denetleme yetkisi karşılığında bu konumu kabul etmiştir. Suudi kralları ulemanın statüsüne saygı göstermiş ve Suud ailesinin İslami konumunu etkileyebilecek hususlarda onların onayını almaya dikkat etmiştir. İki taraf arasındaki bu ilişki sonucunda ulemaya dâhili politikalar noktasında birçok tasarruf ve denetleme yetkisi verilirken, onların dış politikadan, siyasi karar merkezlerinden ve makro ekonominin düzenlenmesi sürecinden uzaklaştırılmaları mümkün hale gelmiştir (Cleveland, 2008: 506-507).

$\mathrm{Bu}$ çerçevede ulema mesela eğitim sisteminin düzenlenmesinde, televizyon gibi kitlesel medya araçlarının denetlenmesinde önemli yetkilere sahip olabilmiştir. 1980'lerden sonra ise toplumu dini kurallara göre denetleme işlevini yerine getiren ve daha sonra krallıktaki yabancıların izlenmesi ve kırsal kesimde İslami öğretilerin yayılması görevlerini de üstlenen Ahlak Polisi, ulemanın denetimi altına verilmiştir. "Böylece kral ailesi genel politikayı kararlaştırıyor, ama ulemaya da kendi isteklerini tatmin edecek ve Suudi hanedanını meşru İslami hükümdarlar olarak desteklemelerini garanti edecek yetkiler veriyordu". Şunu da belirtmek gerekir ki sayıları genişleyen ve kontrol edilmeleri de zorlaşan prenslerin İslami prensiplere uymayan bazı davranışları, kamuoyuna gösterilen ahlaklılık ile özel hayatlarda yaşananlar arasında bir uçurum olduğunu ortaya çıkarmış ve bu durum muhalif bazı çevrelere rejimi ikiyüzlülükle suçlama firsat1 vermiştir (Cleveland, 2008: 506-507).

Suudi hükümetinin din ulemasına ahlak, eğitim ve medyanın ve kamu hayatının denetlenmesi gibi alanlarda yetki vermesine karşılık, onları siyasi ve makro karar alma süreçlerinden uzaklaştırması, demokratikleşme yönündeki değişimlerin gerçekleşeceği mekanizmaların, hem ulemanın hem de diğer kesimlerin eleştiri ve sorgulamasından korunmasinı garanti altına alması anlamına gelmektedir. Suudi uleması gerek Vehhabiliğin katı yapısından dolayı ve gerekse Arabistan'ın coğrafi konumundan ve doğrudan bir sömürge dönemi yaşamamış olmasından dolayı, çağdaş 
değişim süreçlerinden ve demokratik kültür ve eğilimden nispeten uzak kalmıştır. Dolayısıyla ulemanın denetimi, daha çok toplumun ahlaki denetimi üzerinde yoğunlaşmaktadır. Fakat ulemanın bu ahlaki denetimi de daha çok halk düzeyinde gerçekleştiği için, Suudi hükümet ve hanedan üyelerinin her halükarda ulema tarafından denetlenmesi söz konusu olmamaktadır. Fakat diğer taraftan ulemanın Suudi rejimine verdiği meşruiyet ve destek, diğer kesimlerden gelebilecek her türlü saldırı ve sorgulamaya karşı kalkan işlevi görmektedir. Diğer bir ifadeyle Suudi rejiminin hukuki, siyasi ve demokratik değişimine yönelik her teşebbüs, ulemanın destek ve katkısıyla, İslami bir yönetimi zayıflatmak isteyen "kötü niyetli ve bozguncu" bir teşebbüs konumuna düşürülmektedir.

Diğer taraftan devletin resmi dini mezhebi olan Vehhabilik dışındaki İslam mezheplerinin ve bilhassa Şia mezhebinin mensupları takip edilmekte ve dışlanmaktadır. Bu dışlanma ve kontrol aslında "tevhit inancına uygun tek yolun Vehhabilik olduğu" şeklindeki dini bir argümana dayandırılarak yapılsa da (Kalpakian, 2009: 357) bunun siyasi sonuçları da olmaktadır. Bu şekilde kaynağı ve merkezi Arabistan içerisinde yer alan ve Suudi yönetimiyle güvenilir bir ittifak içerisinde bulunan Vehhabilik, İngiltere'nin Angilikan Kilisesi veya Rusya'nın Ortodoks Kilisesi gibi milli bir dini kurum haline getirilmiş olmaktadır. Bunun neticesinde de rejimin istikrarına zarar verebilecek dini hareketler ya dışlanarak veya devletle ittifaka sokularak etkisiz hale getirilmiş olmaktadır.

\subsubsection{Güvenlik Güçleri}

Suudi devletinde siyasi değişime ve sosyal çalkantılara karşı mevcut rejimi koruyan mekanizmalardan biri de güvenlik güçlerinin güvenilirliği ve yönetilme biçimidir. İç güvenliği sağlayan en önemli mekanizmalar -polis, istihbarat teşkilatı, İçişleri Bakanlığı yönetimindeki özel kuvvetler ve Milli Muhafizlar- siyasi olarak güvenilir konumdadır ve rejime bağlıdır. Bahsi geçen bu kuvvetlerin elemanları çoğunlukla, rejimin özellikle kendisine sadık gördüğü Sünni kabilelerin üyeleri arasından devşirilmektedir.

Suudi silahlı kuvvetlerinin ve güvenlik güçlerinin bizzat kendilerinin rejime yönelik bir tehdit oluşturmalarını engelleyen diğer bir nokta da bu kuvvetlerin Misır veya Tunus'ta olduğu gibi siyasi kurumlardan bağımsız bir yap1 olarak ortaya çıkmasına izin verilmemesidir. Hanedan üyeleri çeşitli silahlı birliklerin sadece komuta kademesinde değil üst kademe subaylıklarında da önemli görevler üstlenmiştir. Ayrıca silahlı güvenlik unsurları birbirinden ayrı birkaç teşkilat halinde yapılandırıldığından, bunların birleşerek rejime darbe veya vesayet tehdidi oluşturmaları zorlaştırılmıştır. Diğer taraftan da bu kuvvetler, son yıllarda Yemen, Libya gibi ülkelerde müşahede edilen askeri yapıların aksine, çökmesini ve parçalanmasını önleyecek şekilde profesyonel ve iyi bir eğitimden geçirilmişlerdir (Gause, 2011: 6-7). 
Yalova Sosyal Bilimler Dergisi

\subsection{Suriye}

Suriye'nin önceki devlet başkanı olan Hafız Esad, sosyalizm ile Arap milliyetçiliğini birleştiren bir doktrin ve siyasi hareket olarak Baas Partisini, iktidarını pekiştirip sürdürmenin bir aracı olarak değerlendirmiş ve devlet başkanlığı ile birlikte parti genel başkanlığını da elinde tutmaya devam etmiştir. Baas partisinin siyasi sistemi ayakta tutma noktasında yerine getirdiği en önemli işlevlerden birisi toplumun, siyasi iktidarın istediği şekilde indoktrine edilmesidir (Arı, 2012: 147). Bu şekilde Suriye'de siyasi sistem genel hatlarıyla otoriter bir yapı arz etmesine rağmen, Baas Partisi, totaliter sistemlerdeki partilerinkine, bilhassa sosyalist ülkelerdeki Komünist Partininkine benzer bir indoktrinasyon fonksiyonunu yerine getirmiş olmaktadır. Zaten Baas Partisinin dayandığı temellerden birinin Sosyalizm olması bu paralelliği izah edebilecek niteliktedir.

Esad'ın iktidarını ve siyasi rejimi güvence altına almak için başvurduğu diğer önemli bir enstrüman da yönetimin üst düzey ve kritik pozisyonlarına güvendiği kimseleri, yakın çevresini ve akrabalarını yerleştirmesidir. Bu noktada Esad'ın Suriye sosyal yapısı içerisinde azınlık bir unsur olan Nusayriliğe mensup olmasının bir neticesi olarak, iktidarın hükümet kanadının birçok kademesine, aynı şekilde askeri bürokrasinin ve istihbarat teşkilatının da en önemli mevkilerine Nuseyriler ve Lazkiye kökenliler yerleştirilmiştir. Benzer şekilde savunma sanayiini oluşturan şirketlerin yönetimine de umumiyetle Nuseyriler getirilmiş, daha alt kademelerde görev alabilen Sünnilerin de eski şehirli siyasi ve sosyal elitten olmamasına dikkat edilmiştir (Arı, 2012: 147; Sadowski, 1988: 160-184).

\subsection{Rusya}

2000 yılından bu yana Rusya'nın siyasi sistemi şu anki cumhurbaşkanı Putin tarafindan dizayn, tanzim ve kontrol edilmektedir. 1993 Anayasasının Rusya'ya istikrar getirme amacıyla siyasi gücü cumhurbaşkanlığında yoğunlaştırması ve daha sonraki bir düzenlemeyle cumhurbaşkanının iki dönemden sonra bir dönem ara verdiği takdirde tekrar seçilebilmesinin yolunun açılması ve son olarak Rusya'da demokratik kurumsallaşmanın henüz tamamlanmamış olması, cumhurbaşkanının şahsına endeksli bir sistemle ülkeyi yönetmesini kolaylaştırmıştır. Bu şekilde demokratik kurumların kontrol edemediği, kuvvetler ayrımının dengeleyemediği, hukukun üstünlügünün yön veremediği bir sistem, hâkim şahısların tasarruf ve takdirlerine dayalı olarak yönetilmeye başlamış ve bu çerçevede birçok keyfi uygulama Rusya siyasetini şekillendirmiştir. Böylece kurumsal ve hukuki kriterlerin sınırlamalarından kurtulan siyasi irade, hem kendi hâkimiyetini tahkim etmiş hem de Rusya'nın uluslararası alandaki üstünlük iddialarını gerçekleştirme teşebbüsüne girişmiştir. Yani içerde ve dışarda üstünlük kurma emellerine dayanan yeni Rus-Putin paradigması, reel politiğin sınırsız enstrümanları ile korunmaya başlanmıştır. 
Yalova Sosyal Bilimler Dergisi

\subsubsection{Siyasi, Demokratik ve Adli Kurumların Manipülasyonu}

Putin döneminde Seçim ve Siyasi Partiler Kanunlarının getirdiği zorlayıcı ve kısıtlayıcı şartlarla muhalefetteki partilerin seçimlere katılması ve seçimlerden başarılı sonuçlar alabilmesi zorlaştırılmış ve cumhurbaşkanına bağlı olan iktidardaki partinin, meclisin alt kanadında ezici bir çoğunluk sağlaması mümkün hale getirilmiştir. Ayrıca verdiği bazı kararlardan anlaşıldığı gibi, Anayasa Mahkemesi, Kremlin'in argümanlarını kabule meyilli olduğunu göstermiştir (Zaznaev, 2008: 34-36).

Diğer taraftan Rusya'daki seçimlerin yapılma sürecinde çeşitli manipülasyon iddiaları ve yolsuzluk şaibeleri tartışılmaktadır. Mesela 2007 seçimlerinde gerçekte rekabetçi bir seçim sürecinin işlemediği, muhalif liderlerin baskı ve taciz gördüğü, seçim kanununun demokratik serbestliği tahdit ettiği ve oylama sürecinde yolsuzluk yapıldığı iddia edilmiştir (DeBardeleben, 2008: 275-276).

\subsubsection{Siyasi Gücün Dikey ve Yatay Planda Başkanlık Makamında Temerküzü}

Önceki Rusya Devlet Başkanı Boris Yeltsin bölgesel unsurların desteğini almak amacıyla siyasi güç ve yetkileri Moskova'dan bölgelere doğru dağıtmıştı. Yeltsin'den sonra göreve gelen Putin bu eğilimi tersine çevirmeye başladı. Putin ilk günden itibaren değişik yerlerde yaptığ konuşmalarda Rusya'nın geçmişten bu güne merkezileşmiş bir devlet geleneğine sahip olduğunu, bundan sonra da bunun böyle devam edeceğini ifade etti. Putin daha sonraki yillarda siyasi sistemde bu çerçevede bazı değişiklikler yaptı: Önce bütün Rusya'yı kapsayan ve her birinin başında bir Kremlin temsilcisinin bulunacağı yedi idari bölge ihdas etti. Daha sonraki süreçte, 178 bölge valisinin atanması sürecini, cumhurbaşkanının aday göstermesi üzerine bölgesel meclis tarafından onaylanması biçiminde değiştirdi. Yine meclisten çıkarılan bir yasayla devlet başkanına bölgesel valileri görevden alma ve bölgesel meclisleri dağıtma yetkisi verildi (Kotz \& Meir, 2007: 277-278).

Devlet yapısını dikey çerçevede güçlendiren bir değişiklik de federal ve bölgesel yönetimler arasındaki ekonomik (bütçe ile ilgili) ilişkilerin federal bütçe lehine değiştirilmesi ve bu şekilde bölgesel yönetimlerin ekonomik olarak merkeze bağımlı hale getirilmesidir (Zaznaev, 2008: 34-36).

Cumhurbaşkanı Putin'in siyasi gücünü otoriter bir düzlemde garanti altına aldığı diğer bir araç da güvendiği adamları önemli pozisyonlara yerleştirmesidir. $\mathrm{Bu}$ güvenilen adamlar tabii ki KGB saflarından gelen insanlardır. Bu insanların petrole, gaza, silah sanayiine, bankacılığa ve başka bazı kilit endüstrilere büyük bir ilgisi vardır. Ülkeyi bu insanlar yönetmekte ve ülkenin ekonomik kaynaklarına bu insanlar sahip olmaktadır. Dolayısıyla Putin "KGB devleti" haline getirdiği bir yapıda güçlü pozisyonunu bu şekilde sürdürebilmekte ve demokratik hareketleri rahatlıkla bertaraf edebilmektedir (Voren, 2009: 262). 
Yalova Sosyal Bilimler Dergisi

\subsubsection{Siyasi Gücün Elindeki Ekonomik ve Askeri Araçlar}

Rusya'nın iç ve dış siyasetteki otoriterizmini destekleyen ve mümkün kılan en önemli faktörlerden birisi de enerji potansiyeli ve askeri kapasitesidir. Genellikle kabul edildiği gibi ekonomik zenginlik, reel ekonomik dinamiklere ve üretim süreçlerine dayanmadığı zaman, demokratikleşmeyi olumsuz etkileyen bir faktör haline gelmektedir. Çünkü bu durumda bütün eğitim, kültür, donanım ve formasyonuyla birlikte orta sınıf oluşmamaktadır. Devlet elinde tuttuğu petrol, doğalgaz gibi ekonomik kaynaklarla toplumun geniş kesimlerini kendine bağımlı hale getirmekte ve muhalefet potansiyelini zayıflatmaktadır.

Rus yönetimi de elindeki Petrol ve Doğal Gaz imkanlarını benzer şekilde, siyasi iktidarını konsolide etmek için kullanmaktadır (Goldman, 2008). Son yıllarda petrol fiyatlarında meydana gelen düşme eğer uzun bir süre devam ederse, siyasi iktidarın bu alandaki avantajını zayıflatabilir.

Diğer taraftan askeri güç kapasitesi, dış siyaset alanında siyasi iktidarın elini güçlendirmekte ve uluslararası sistemden gelebilecek istikrarsılaştırıcı etkileri zayıflatmaktadır. Bu aynı zamanda uluslararası aktörlerle pazarlık konusunda iktidara siyasi bir koz sağlayarak, ekonomik ve ticari ilişkilerde de bir avantaj haline gelebilmektedir.

\subsection{Kuzey Kore}

Kuzey Kore, komünist devlet sistemi, şahsi diktatörlük ve hanedan monarşisinin karşımı olan melez bir yapıdır. Bir taraftan Kore İşçi Partisi Komünist Sistemlerdeki Komünist partinin tek parti hâkimiyetine benzer bir kontrolü icra ederken, diğer taraftan devlet başkanının çok geniş, hatta mutlak yetkileri bulunmakta ve yine devlet başkanlığının bu güne kadarki üç başkanının tevarüse dayanması hanedan monarşilerini andırmaktadır.

\subsubsection{Kore İşçi Partisi}

Diğer Komünist ülkelerde olduğu gibi, Kuzey Kore'de de devlet yapısı hâkim tek parti olan Kore İşçi Partisine tabi olacak şekilde düzenlenmiştir. Devlet, hâkim pozisyonunu, işçi sınıfının temsilcisi olması iddiasına dayandıran partinin şekillendirdiği politikaları uygulamaktadır. Fakat uygulamada 1972 anayasa değişiklikleri siyasi güç merkezini partiden, başkana doğru kaydırmıştır (Park, 2006: 738).

\subsubsection{Başkanlık Makamı}

Kuzey Kore devletinin kurucusu, ilk başbakanı ve 1972 anayasa değişikliğinin kabulünden sonra ilk devlet başkanı olan Kim İl Sung, milli bağımsızlık mücadelesine 
öncülük eden ve devleti kuran diğer bazı otoriter liderlerde olduğu gibi, bu özelliğini siyasi gücü kontrolü altına almak ve rakiplerini tasfiye etmek için bir dayanak olarak kullanmıştır.

Sung, 1962'ye kadar Kore İşçi Partisi üzerinde ve dolayısıyla da parti vasitasiyla devlet üzerinde mutlak bir kontrol kurmuştur. O elindeki Kapsan gerilla birliğinin, sosyalist olanlar da dâhil, bütün rakiplerini tasfiye etmesiyle, pozisyonunu güçlendirmiş ve devlet aygıtının mutlak hâkimi durumuna gelmiştir. Sung ülkesinde Stalin ve Mao’yu bile gölgede bırakacak şekilde şahsi kültünü tesis etmiş ve yüceltilmiş bir imajla toplumu totaliter bir tahakkümle yönetmeye başlamıştır. 1994'te Sung'un ölümü üzerine yerine geçen oğlu Kim Jong İl kendi şahsi kültünü kurarak babasının politikalarını sürdürmüş ve Kuzey Kore toplumunun her alanını sıkı şekilde kontrol altında tutmaya devam etmiştir (Park, 2006: 738).

Kim Jong Il de babası gibi şahsi kültüyle kendisini güçlü bir lider konumuna getirmiştir. $\mathrm{O}$ da babası gibi muhtemel rakiplerine karşı acımasız olmuştur. O teşkilat düzeyindeki direnişleri kırmak için siyasi tasfiye yolunu kullanmıştır. Başkan Il, kontrol eğilimli bir siyasi karakterdir. Hiç kimseye güvenmez ve önemli bütün bilgilerle bizzat kendisi ilgilenir. Partinin ve Güvenlik Departmanının başkanıdır. "O kadrosuna karar alma konusunda özerk bir alan sağlayan bir lider değildir. Karar alma sürecinde bürokrasi içerisinde herhangi bir dirençle karşılaştığı zaman, bürokratlar üzerindeki kontrolünü güçlendirerek bunun üstesinden gelir. Başkan Il parti, polis, gizli polis ve toplama kampları gibi kontrol ve sindirme kurumlarını yaygınlaştırarak halk1 takip etmekte ve yabanc1 unsurlar1 rejimden temizlemektedir" (Lim, 2009: 173).

2011'de başa geçen Kim Jong Un, büyük ölçüde iki atasının Komünist totalitarizm ve lider kültüyle sindirilerek etkisiz hale getirilmiş bir siyasi toplumda seleflerinin kurduğu sistemi büyük ölçüde devam ettirmeye çalışmaktadır. Fakat Un'un selefleri kadar karizmatik olmaması ve ciddiyetten uzak bazı uygulamalarının olması uzun vadede otoritesini tartışmaya açabilecek bazı hususlar olarak göze çarpmaktadır.

\section{Etkileri}

\section{Koruyucu Faktör ve Mekanizmalar ve Bunların Demokratikleşmeye}

Asya ve Ortadoğu'daki antidemokratik sistemlerle ilgili yukarıda açıklanan koruyucu mekanizmaların farklı sonuçları olması tabiidir. $\mathrm{Bu}$ mekanizmaların bir kısmının aynı zamanda milli bağımsızlığı, ülke bütünlüğünü koruma gibi fonksiyonları olabilir. Fakat bunların çoğunun mevcut anti-demokratik rejimi koruyarak, demokratikleşme yönündeki reform ve değişim çabalarını engelleme işlevi gördüğü de aşikârdır. Bu çerçevede bu bölümde bu koruyucu mekanizmaların her biri ayrı ayrı değerlendirilerek demokratikleşmeye negatif etkileri açıklanmaya çalışılacaktır. 
Yalova Sosyal Bilimler Dergisi

\subsection{Rejime Bağlı Silahlı Kuvvetler, Güvenlik Güçleri ve İstihbarat Örgütleri}

Meşruiyetini demokratik süreçlere dayalı olarak yenileyip güçlendiremeyen siyasi sistemlerin, kuruluş aşamasında belli ölçüde meşruiyeti olsa bile zamanla bu meşruiyetin aşınıp zayıflayacağı siyasi bir realitedir. Diğer taraftan meşruiyetle zor kullanma ihtiyaç ve eğiliminin birbiriyle ters orantılı olduğu da yine siyaset bilimince kabul edilen bir olgudur (Roscin vd., 2012:24). Yani bir siyasi rejimin meşruiyeti azaldıkça ve halk rejimin dayanacağı bir destek tabanı olma özeliğini kaybetmeye başladıkça, rejim, halkın dışında destek dayanakları aramaya başlayacaktır ki bunların en önemlilerinden biri kendine sadık silahlı kuvvetler, güvenlik güçleri ve istihbarat örgütleridir.

İran'daki Devrim Muhafızları siyasi rejimi koruyan bu tür yapılardan biridir. Genellikle birçok ülkede 'muhafız' adı altındaki silahlı güçler, yönetim merkezini korumakla görevli sınırlı sayıdaki kuvvetlerden oluşurken, İran'daki Devrim Muhafızları, sayı, kapasite ve sistemdeki etki derinliği bakımından konvansiyonel ordunun dışında ikinci bir ordu konumundadır ve hatta İran ordusundan daha etkili ve güçlüdür. Doğrudan Dini Lidere bağlı olması rejimi tahkim etme noktasındaki rolünü ortaya koymaktadır. Bu kuvvet, 2009'da yaşanan olaylarda görüldüğü gibi, demokratikleşme isteklerine veya daha dürüst ve şeffaf seçim taleplerine yönelik hareketleri şiddetle bastırmaktadır.

Suudi Arabistan'da, Suriye'de ve Saddam dönemi Irak'ta genellikle ordunun komuta kademelerine devlet başkanının akrabasından ve yakın çevresinden insanlar yerleştirilmektedir. Suriye ve Irak'ta ve belli bir ölçüde Türkiye'de siyasi rejimin ideolojisi ve değerleri çerçevesinde, orduya alım sırasında asker adayları sıkı bir kontrolden ve yetiştirme döneminde sıkı bir eğitim ve indoktrinasyon sürecinden geçirilmektedir. Suriye ve Irak'ta hâkim ideoloji Baasçılık (Sosyalist Arap milliyetçiliği), Türkiye'de ise Kemalizm'dir. Suriye'de ayrıca ordunun üst ve orta kademelerini 1930'lardan beri Nusayri azınlıktan insanlar doldurduğundan, 1970'lerde askeri darbeyle başa geçen Nusayri rejim, Sünni çoğunluğun demokratik baskısını kırmak için bu askeri yapıya dayanmaktadır. 2000 yılında Suriye devlet başkanlığına gelen Hafız Esad'ın oğlu Beşşar Esad, mevcut Suriye siyasi yapısını büyük ölçüde koruyarak devam ettirmiştir. Suriye'deki rejimin, Arap Baharı döneminde başlayan demokratik reform taleplerini ordu ve istihbaratı (Muhaberat) kullanarak şiddetle bastırmaya çalışması, halkın çoğunluğunun nazarında meşruiyetini sıfıra indirmiş ve bu şekilde ülkede iç savaş başlamıştır.

\subsection{Hukuki Mekanizmalar}

Hukuki mekanizmaların demokratikleşmeyi engelleyici ve antidemokratik sistemi koruyucu bir işlev görebilmesi için, sistem içerisinde kısmen de olsa bazı demokratik unsurların yer alması veya sistemin kendisini halkın iradesine dayalı bir yönetim olarak sunmaya çalışması gerekir. Diğer bir ifadeyle, mesela totaliter 
Yalova Sosyal Bilimler Dergisi

sistemlerde zaten totaliter kontrolü sağlayan parti ve ordu gibi güçlü ve mütehakkim mekanizmalar bulunduğundan, hukuki araçların kullanılmasına çok fazla ihtiyaç kalmamaktadır.

$\mathrm{Bu}$ noktada İran, Rusya ve Türkiye, siyasi sisteminde bazı demokratik unsurlara yer veren veya halka dayalı yönetimler olma görüntüsü vermeye çalışan ülkelerden bazılarıdır. İran'ın anayasal düzenindeki Koruyucular Konseyi, Rusya'daki mahkemeler ve Türkiye'de bilhassa 1962-2010 dönemindeki uygulamalarıyla Anayasa Mahkemesi ve lağvedilen Devlet Güvenlik Mahkemesi, demokratik gelişmenin zayıflatılması pahasına, bu ülkelerin siyasi rejimlerini koruyucu ve muhalefet hareketlerini etkisizleştirici kararlar almışlardır. İran'daki Konsey siyasi ve ideolojik perspektifle yasaların anayasal denetimini yapmakta ve siyasi sistemin hukuki temeller üzerinden bir değişime maruz kalmasını engellemeye çalışmaktadır. Milletvekili adaylıklarını yine siyasi sistemin ve kurulu düzenin öncelik ve hassasiyetlerini esas alarak denetlemekte ve meclis çatısı altında siyasi çoğulculuğa zemin hazırlayabilecek bir milletvekili çeşitliliğinin önünü en baştan kapatmaktadır.

Türkiye'de Anayasa Mahkemesi tarihinde birçok defa, şiddete ve teröre bulaşmamış siyasi partileri ideolojik bir taraflılıkla kapatmış veya bu partilere evrensel demokratik standartlara göre suç teşkil etmeyen işlem ve eylemleri için yaptırım uygulamıştır. Bu uygulamalarıyla Anayasa Mahkemesi, çoğulculuğun ve çok sesliliğin garantisi olması gereken siyasi partileri tek tipleşmeye zorlayarak, Türkiye'de demokratik alanın daralmasına yol açmıştır. Yine lağvedilen Devlet Güvenlik Mahkemesi sol ve sağ grupların ifade ve örgütlenme hürriyeti, toplantı ve gösteri yürüyüşü hakkı gibi bazı sivil haklarını kısıtlayan bazı kanunlara dayalı olarak, katı bir hukuki pozisyon benimsemiş ve Kemalist rejime muhalif gördüğü kesimleri ve kişileri etkisiz hale getirmeye çalışmıştır.

Kurumsallaşma, tarafsızlık ve hukukun üstünlüğü gibi bazı süreçleri henüz tamamlayamamış olan Rus mahkemelerinin de yürütmenin eğilimleri istikametinde hareket ettiğine dair birçok delil bulunmaktadır. Genellikle hükümeti veya devlet başkanını eleştiren veya bunlara muhalefet etmeye başlayan kimselerin çok geçmeden çeşitli iddialarla mahkeme karşısına çıkarıldıkları ve mahkûm edildikleri görülmektedir. İstihbaratın örtülü bir takım tehdit ve baskılarıyla birleştiği zaman mahkemelerin bu taraflı ve angaje olmuş tavrı, demokrasinin önemli bir unsuru olan muhalif hareket ve örgütlenmelerin zayıflatılmasına ve sindirilmesine yol açmaktadır.

\subsection{Siyasi ve İdari Pozisyonların Devlet Başkanının Yakınlarınca Kontrol Edilmesi (Nepotizm)}

Antidemokratik devletlerde siyasi rejimin meşruiyeti halka ve demokratik kontrol mekanizmalarına dayanmadığından, bu devletlerin yönetimine hâkim olanlar, devlet aygıtının yönetim unsurlarını paylaşacakları kimselere güvenmeme eğilimindedirler. $\mathrm{Bu}$ tür sistemlerde iktidara geliş ve iktidardan ayrılma düzenli demokratik süreçlerle olmadığından, yönetimi değiştirmek için darbe, ayaklanma, 
komplo gibi sıra dışı yollara başvurulmaktadır. Bu sebeple antidemokratik bazı sistemlerde hâkim unsurlar, kendi akrabasından insanları üst düzey siyasi ve idari pozisyonlara yerleştirerek, iktidarlarını garanti altına almaya çalışmaktadırlar. $\mathrm{Bu}$ şekilde kendi iktidarlarına yönelik olarak hem halktan gelebilecek tehditlere karşı bu üst düzey kadro bir paratoner işlevi görmekte, hem de siyasi ve idari yapının kendi içinden gelebilecek tehlikeli girişimler önlenmiş olmaktadır. Her iki şekilde de sistemi demokratik reform yapmaya zorlayabilecek baskılar ister halk tabakasından, isterse siyasi ve idari elit kesiminden gelsin, etkisiz hale getirilmiş olmaktadır.

Siyaset ve sosyoloji literatüründe bu durum 'Nepotizm' kavramıla ifade edilmektedir. Aslında Nepotizm kavramıyla ilgili açıklamalarda daha çok devlet mevki ve imkânlarının yakın çevrelere dağıtılması ve akrabadan insanların bu şekilde kayırılması anlamı üzerinde durulmaktadır. Fakat bu kavramın muktedir ile yakınları arasındaki karşılıklı bir çıkar ilişkisine dayandırılması daha doğru bir yaklaşım olacaktır. İktidar sahibi yakınlarına imkânlar ve pozisyonlar bağışlayacak, onlar da güvenilir insanlar olarak onun iktidarını güvence altına altmış olacaklardır.

Yukarıda değinildiği üzere, monarşiye dayalı bir siyasi sistem olan Suudi Arabistan'da iktidar değişimi kurucu lider Abdülaziz'in oğulları arasında gerçekleştiği gibi, siyasi ve idari yapının üst düzey ve kilit önemdeki pozisyonları yine Abdülaziz'in oğulları veya torunları tarafından üstlenilmektedir. Kurucu liderin kırk civarında erkek çocuğunun ve yüzlerce torununun olması böyle bir uygulama için yeterli kadroyu mevcut hale getirmiştir.

Suudi Arabistan'daki siyasi sistemle oldukça farklı bir siyasi ve ideolojik yapıda olsalar da Suriye ve eski Irak devlet başkanları da benzer bir yol izlemişlerdir. Gerek Saddam Hüseyin ve gerekse baba-oğul Esadlar siyasi ve idari yapının kilit mevkilerine kendi akrabalarını veya yakın çevrelerini yerleştirerek siyasi iktidarlarını ve dolayısıyla mevcut rejimi korumaya çalışmışlardır. Bunun bir adım daha ötesinde Saddam'ın Şii çoğunluğa karşı Sünni kesimleri, Esadların ise Sünni çoğunluğa karşı Nusayri azınlığı devlet kademelerine yerleştirdiği görülmektedir. Böyle bir uygulama ile çıkar çeşitliliğinin yönetime yansıtılması anlamında çoğulculuk engellenmekte, değişim taleplerine yol açabilecek sosyal dinamikler zayıflatılmakta ve uluslararası hukukça suç sayılan polis devleti uygulamalarının iç veya dış kamuoyundan gizlenmesi mümkün olmaktadır.

\subsection{Totaliter Tek Parti}

Rekabete ve çoğulculuğa dayalı çok partili sistemler demokratik hayatın en önemli unsurlarından ve göstergelerinden biridir. Dolayısıyla demokratik olmayan modern siyasi sistemlerin hemen tamamında toplumu kontrol ve dizayn etmek için tek parti hakimiyeti uygulanmaktadır. Antidemokratik sistemlerdeki tek partiler, Suriye'de olduğu gibi toplumun siyasetten uzak tutulmaya çalışıldığ 1 sistemlerde, daha çok siyasi elitin şekillendirildiği ve devlet politikalarının geliştirildiği bir laboratuvar işlevi görmektedir. Toplumun siyaseten mobilize edilmeye çalışıldığı Kuzey Kore, Nasır 
Yalova Sosyal Bilimler Dergisi

dönemi Mısır gibi örneklerde ise zikredilen bu işleve ilaveten parti, toplum kesimlerini ve yeni nesilleri hâkim ideoloji ve/veya lider kültü etrafında yönlendirmekte ve bu kesimlerin sisteme ve lidere bağl11ıklarını sürekli canlı tutmaya çalışmaktadır.

Fakat her iki durum da demokratik gelişme açısından pek elverişli bir durum arz etmemektedir. Çünkü ister siyasi elitin yetiştirilmesi ve politikaların geliştirilmesi açısından olsun isterse toplum kesimlerinin siyasi mobilizasyonu açısından olsun, antidemokratik tek partilerin uygulamaları, demokratik sistemlerde olduğu gibi aşağıdan yukarıya doğru değil, yukardan aşağıya doğru bir dönüşümü öngörmektedir. Dolayısıyla toplumun beklenti ve taleplerini, bilhassa sivil toplum gibi sivil kanallar aracılığıyla yönetim ve karar alma mekanizmalarına iletmesine imkân vermeyen birçok "toplum mühendisliğì" çabası gibi tek partinin faaliyetleri de demokratikleşmeyi teşvik etmek bir tarafa, onu geciktirme amacı taşımaktadır. Çünkü mesela mobilizasyon uygulaması, siyasi sistem ile halk kesimlerinin düşünce ve anlayışları arasındaki tezatları gidermek ve sistemin meşruiyet temelini güçlendirmek için, sistemin yapısında değişiklik yapmak yerine, halkın anlayış ve zihniyetini biraz da zor ve baskı uygulayarak değiştirme amacını ifade etmektedir.

Komünist ve faşist yapıdaki sistemlerde tek partiler totaliter bir faaliyet tarzı izlemekte, toplum hayatının bütün yönlerini kontrol ve dizayn etmeye çalışmaktadır. Otoriter sistemlerdeki partilerin ise bazıları toplum kesimlerini mobilize ederek, bazıları ise apolitize ederek rejimi konsolide etmeye çalışmaktadır.

\subsection{Rantiyeci Devlet Yapısı}

Rantiyeci devlet yapısı, devletin ülkedeki ekonomik kaynakların veya üretim araçlarının birçoğunu elinde tutarak, toplumu ekonomik olarak kendisine bağımlı hale getirdiği ve kaynak ve imkânları dağıtmak suretiyle toplum üzerinde kontrol sağlayabildiği bir yapıdır. Özellikle Orta Doğu ve Asya'daki anti-demokratik devletlerin mevcut ekonomik uygulamalarına bakıldığında belli başlı iki durumun bulunduğu göze çarpmaktadır: Birinci durumda devletçilik ve merkezi ekonomi uygulanmakta ve istihdam alanlarının tamamına yakını devletin elinde bulunmaktadır. Abdunnasır dönemindeki Mısır, tek parti dönemindeki Türkiye ve Kuzey Kore gibi sosyalist ekonomi uygulayan ülkeler buna örnek gösterilebilir. İkinci grupta ise petrol, doğalgaz kaynakları bol olmakla birlikte reel yerli sanayisi gelişmemiş olan ülkeler bulunmaktadır ki buna da Suudi Arabistan ve diğer Körfez krallıkları, Rusya, Azerbaycan gibi ülkeler örnek verilebilir. Bu ülkelerde de devletin önemli gelir kaynakları siyasi ve idari kadrolar tarafından dağıtıldığından, sivil toplum kesimlerinin rejim karşısındaki bağımsızlığı ve dolayısıyla muhalefet potansiyeli büyük ölçüde zayıflatılmış olmaktadır.

Devletin ekonomiye müdahaleciliği, zayıf durumdaki siyasi meşruiyeti güçlendirme amacıyla izlenen ekonomik politikalarla birleşince birçok Orta Doğu ülkesinde rantiyeci ekonomi uygulamaları ortaya çıkmaktadır. Böyle bir ekonominin ortaya çıkması sonuç olarak toplumun ekonomik alanda devlete karşı özerkliğini 
Yalova Sosyal Bilimler Dergisi

azaltmakta ve bu da "aşağıdan yukarıya doğru" demokratikleşme imkânını zayıflatmaktadır (Kamrava, 2005: 266-267).

Sivil toplum ile demokratikleşme arasındaki ilişkiyi değerlendiren birçok siyaset bilimci, sivil toplum alanının güçlenmesinin ve bu tür oluşumların kültürel bir altyapı halinde gelişip yayılmasının, demokrasinin gerek yerleşmesi ve gerekse süreklilik kazanarak konsolide olması açısından önemli olduğunu vurgulamaktadır. Diğer taraftan mesela sivil toplumun Batı'da gelişmesini sağlayan en önemli dinamiklerden biri, erken modern dönemde Avrupa'da ticari hayatın canlanması ve özerk korporasyonların yaygınlaşarak müstakil bir sivil alan meydana getirmeleridir. Dolayısıyla birçok yazar serbest piyasa şartlarının varlığı, özel ekonomik faaliyetlerin yaygınlığı ve kamu dışı ekonomik oluşumların kendi ayakları üzerinde durabilmesi ile demokratik gelişme arasında yakın bir ilişki kurmaktadırlar.

\subsection{Demokratik Seçime Dayanmayan Yönetim Mevkilerindeki Orantısız Siyasi Güç Temerküzü}

İran'da Dini Lider, Kuzey Kore'de devlet başkanı ve Suudi Arabistan'da kralın çok geniş yetkileri bulunmaktadır. Bu yetkilerin 'anayasa' adındaki bir metinde tanımlanıp tanımlanmaması, yetkinin otokratik bir yapılanma doğurması gerçeğini değiştirmemektedir. Böyle bir pozisyonun düzenli, rekabetçi ve şeffaf bir seçime dayanmaması, bunun demokratik değişime kapalı olduğunu göstermektedir. Diğer taraftan siyasi gücün orantısız bir şekilde belli bir kişide temerküzü, kuvvetler ayrımının ve siyasi güç dağılımının demokratik sistemlere sağladığı kontrol ve denge sistemini tamamen devreden çıkarmış olmaktadır.

Rusya'daki cumhurbaşkanlığı makamında da aslında bir siyasi güç temerküzü mevcuttur. Bunun yukarıda zikredilenlerden tek farkı seçime tabi olmasıdır. Fakat mevcut cumhurbaşkanı Putin cumhurbaşkanlığı görev süresini iki dönemden sonra bir dönem ara verilmesi şartıyla sınırsız hale getirmiştir. Seçimlerin güvenilirliği ve muhaliflerin siyasi hakları ile ilgili bazı kuşkuları da dikkate aldığımızda, Putin'in demokratik yapının sınırlandırıcı bazı mekanizmalarını aşmaya çalıştığı görülmektedir.

\subsection{Eğitim Sisteminin Çarpıtıcı Etkileri}

Antidemokratik sistemlerin birçoğunda olayların farklı yönleriyle öğrenilmesini sağlayan aydınlatıcı ve objektif bir eğitim sistemi mevcut değildir. Bilakis dünyadaki gelişmeleri, tarihteki olayları, siyasi sistemle ilgili olguları çarpıtarak, taraflı ve tek yönlü şekilde öğreten eğitim sistem ve müfredatları uygulanmaktadır. Bu eğitim sistemleri halk kitlelerine nüfuz edemese de sivil ve askeri bürokrasiyi dolduracak kadroları dünyadaki gerçeklerden ve halkın çıkar ve beklentilerinden kopuk şekilde yetiştirmekte ve her şartta sistemin payandası olabilecekleri bir anlayışla şekillendirmektedir. Bu şekilde halkın çevresine yakın ve şartlarından haberdar olan kesimler zayıf ve etkisiz bir halde kalırken, siyasi, idari ve 
Yalova Sosyal Bilimler Dergisi

hatta ekonomik alanlarda güç ve yetkiyi elinde tutan elitler, önyargılı ve saplantılı bir ideolojik zihniyetle halktan uzaklaşmış olmaktadır.

Türkiye, Baas hâkimiyetindeki Irak, Suriye, Mısır gibi ülkelerde modernleşmeci, milliyetçi, merkeziyetçi, pozitivist, seküler ve Batı kültürüyle uyumlu bir eğitim sistemiyle elit kesimler siyasi sistemi destekleyici bir araç kıvamına getirirken, İran, Kuzey Kore, Çin gibi ideolojik devletlerde belli bir ideoloji ve dünya görüşünün kılıfı altında, milliyetçi ve emperyalist bir çerçevede ve bazen lider kültüne bağlı bir elit kadro yetiştirilmeye çalışılmaktadır. Rusya, Suudi Arabistan gibi ülkelerde ise milliyetçi veya mezhepçi bir yönelişle birlikte lider figürünü de vurgulayan bir eğitim verilmektedir.

\subsection{Büyük Dış Güçlerin ve Uluslararası Sistemin Etkileri}

Orta Doğu ve Asya'daki antidemokratik sistemlerin birçoğunda siyasi rejimin korunmasında ve demokratikleşmenin engellenmesinde büyük dış güçlerin müdahalelerinin önemli bir rolü bulunmaktadır. Buradaki ilginç bir nokta şudur ki ABD, İngiltere, Fransa, Almanya gibi demokratik ülkelerin, bazı ülkelere yaptıkları müdahalelerle, bu ülkelerdeki demokratik dinamikleri zayıflatmaları, bu güçlerin zaman zaman ileri sürdükleri demokrasi şampiyonluğuyla tam bir tezat oluşturmaktadır. Bu çelişki bu Batılı ülkelerin bazı doğulu ülkelerin demokratikleşme standartlarını sorgularken niyet ve amaçlarının ne olduğu konusunda ciddi kuşkular uyandırmaktadır.

Kuşkusuz ki dış güçlerden gelen müdahale veya antidemokratik rejimlere yönelik destek, sadece Batılı demokratik ülkelerden gelmemektedir. Mesela Rusya, İran ve Suriye'deki otoriter sistemlerle ittifaklar kurarak, bu sistemlerin varlığını koruma altına almış ve demokratik hareketliliğin zayıflamasına yol açmıştır. Rusya bilhassa demokratik kanalları açmaya yanaşmadığı için iç savaşa yol açan ve binlerce vatandaşının öldürülmesine sebep olan Suriye'deki rejime olan desteğini bir an bile geri çekmemiştir.

Şu var ki yukarıda belirtildiği gibi bu noktada Batılı demokratik ülkelerin tavrı da Rusya'dan hiç farklı değildir. ABD müttefiki durumundaki Suudi Arabistan'ın ve diğer Körfez krallıklarının antidemokratik siyasi rejimlerini hiçbir zaman ciddi biçimde sorgulamadığı gibi, Mısır'da demokratik bir gelişim sürecini bizzat müdahale ederek baltalamış ve darbecileri ve darbe yönetimini desteklemiştir. ABD daha önce de ülkesindeki demokratik dinamikleri frenleyen ve demokratik değişim kanallarını kapatan Hüsnü Mübarek iktidarını milyarlarca dolar askeri ve mali yardımla desteklemiştir.

Belirtmek gerekir ki büyük güçlerin bu müdahaleci tavrı, Orta Doğu'daki toplumların başlarındaki baskıcı ve yozlaşmış siyasi rejimleri demokratik ve barışçıl yollarla değiştirme noktasındaki umutlarını büyük ölçüde kırmış ve terörizm gibi illegal ve yıkıcı yapılanmaların sosyal destek kazanmasında en büyük tesiri icra etmiştir. 
Yalova Sosyal Bilimler Dergisi

\section{Sonuç}

Orta Doğu ve Asya'daki antidemokratik sistemlerin bir kısmında ordu ve askeri unsurlar, darbeler yoluyla bizzat iktidarı üstlenmişken ve mevcut rejimin hem sahibi, hem de koruyucusu iken, diğer bazılarında silahlı kuvvetler, güvenlik güçleri ve istihbarat yapıları mevcut rejimin korunması için kullanılan birer araç pozisyonundadır. Dolayısıyla birinci durumda hâkim askeri unsurların demokratik dönüşümü kabul etmesi gerekmektedir. İkinci durumda ise rejimin dönüşümü ile birlikte onun dayandığı kurum ve yapıların da demokratik çerçevede dönüşmesi gerekmektedir.

Bazı antidemokratik ülkelerde yürütmenin belli bir pozisyonu, genellikle devlet başkanlığ̣ çevresinde büyük bir güç yoğunlaşması görülmektedir. Adeta siyasi rejim devlet başkanlığının (veya mesela İran'da Dini Rehberliğin) mihveri etrafında dönmekte ve sistemin bütün organ, araç ve kurumları bu otokratik makamı güçlendirmek için seferber edilmektedir. Bu şekilde bir siyasi güç ve yetki temerküzü, sistemin siyasi ve ekonomik verimliliğini büyük ölçüde azaltmakta ve halkın hayat kalitesini ciddi şekilde düşürmektedir. Aslında böyle bir sürecin tabii sonucu siyasi sistemin meşruiyetinin hızla aşınması ve neticede sistemin kendisini demokratik çizgiler istikametinde yeniden tanzim etmek zorunda kalmasıdır. Fakat yaşanan örnekler uluslararası büyük güçlerin kendi stratejik ve ekonomik çıkarları çerçevesinde bu sürecin tabii neticesine ulaşmasını engellediğini göstermektedir. Aslında yaşanan meşruiyet kaybının aynı zamanda terör hareketlerinin de önemli bir beslenme kaynağı olduğu bir gerçektir. Bu noktada büyük güçlerin kamuoylarının, terör olaylarına kendi siyasi elitlerinin gösterdiği şekilde bakarak dar görüşlü ve perspektifsiz tepkiler vermek yerine, kendi yönetimlerini gereksiz müdahalelerden kaçınmaya zorlaması gerekmektedir.

Demokratik süreçlerin kısmi ve sınırlı şekilde uygulandığı eski Türkiye, İran, Mısır gibi ülkelerde demokratik araç ve süreçlerin siyasi sistemde bir dönüşüme yol açmasını engellemek için, denetleyici bazı kurum ve kurulların devreye sokulduğu

görülmektedir. İran'daki Koruyucular Konseyini ve Türkiye'de Anayasa Mahkemesinin eski yapısını bu çerçevede değerlendirmek mümkündür. $\mathrm{Bu}$ tür kurumların başkan ve üyelerinin belirlenme usullerine göre, değiştirilmeleri ve dönüştürülmeleri daha kolay veya daha zor olabilir. Ama genellikle bunların iktidar merkezinin gidişatına bağlı olarak şekil alacakları söylenebilir. Yani siyasi gücün çekirdeğini oluşturan merkezi yapı demokratik bir çerçevede dönüştürüldüğü zaman bu tabi unsurlar da değişecektir.

İdeolojiler siyasi sistemlere suni bir meşruiyet sağlayan önemli araçlardan biridir. Bazen hâkim sınıfın ekonomik çıkarlarını ve siyasi varlığını garanti altına almak için ideolojik söylemler bir kılıf olarak kullanılabilmektedir. Hâkim unsurların çıkarları birbiriyle uyuştuğu zaman, ideoloji siyasi elit arasında birleştirici bir unsur ve halka karşı hizaya getirici bir gerekçe oluşturabilmektedir. Türkiye'de Kemalizm, İran'da Şii İslamcılık, Suriye ve eski Irak'ta Baasçılık, Kuzey Kore ve Çin'de Komünizm böyle bir işlev görmüştür. İletişim kanallarının ve medya araçlarının 
yaygınlaşması ideolojilerin tek tipçi, irrealist ve taraflı bir bakış açısını empoze etme rolünü büyük ölçüde etkisizleştirmiştir. $\mathrm{O}$ zaman bu ideolojiler siyasi gücün cephesindeki bir beton sıva durumuna gelmektedir. Sıva duvarı güçlendiriyor görünse de sıvanın akıbeti duvarın kendi mukavemetine bağlıdır.

\section{Kaynakça}

Alaedini, P; Namazi, S. ve Potter, L.G. (2006). Islamic Republic of Iran. Schlager, N. ve Weisblatt, J. (Ed.). Political systems and Parties içinde (ss. 619-631). New York: Facts on File.

Ar1, T. (2012). Geçmişten Günümüze Orta Doğu. Bursa: MKM Yayınc1l1k.

Batmaz, N.Y. (2015). Çin Halk Cumhuriyeti. Aykaç B. ve Durgun, Ş. (Ed.). Çağdaş Siyasal Sistemler içinde (ss. 397-420). Ankara: Alter Yayıncılık.

Cleveland, W.L. (2008). Modern Ortadoğu Tarihi. Harmancı, M. (Çev.). İstanbul: Agora Kitaplığı.

DeBardeleben, J. (2008). Russi's Duma Elections and Practice of Russian Democracy. International Journal, 63(2).

Faksh, M.A. (2006). Kingdom of Saudi Arabia. Schlager, N. ve Weisblatt, J. (Ed.). Political systems and Parties içinde (ss. 1166-1174). New York: Facts on File.

Gause, F.G. (2011). Saudi Arabia in the New Middle East. New York: The Council of Foreign Relations Inc.

Goldman, I.M. (2008). Petrostate - Putin, Power and the New Russia. New York: Oxford University Press.

Kalpakian, J. (2009). Political Organization. Maisel, S. and Shoup, J.A. (Ed.). Saudi Arabia and Gulf Arab States Today içinde (ss. 357-360). Volume: 1. Westport: Greenwood Press.

Kamrava, M. (2005). The Modern Middle East. London: University of California Press.

Karpat, K. (2015). Türk Siyasi Tarihi. İstanbul: Timaş Yayınları.

Kesselman, M., Krieger, J. and Joseph, W.A. (2009). Introduction to Comparative Politics. Boston: Houghton Mifflin Harcourt Publishing Company.

Kotz, D.M. and Weir, F. (2007). Russia's Path from Gorbachev to Putin. London and New York: Routledge.

Lim, J.C. (2009). Kim Jong Il's Leadership of North Korea. London and New York: Routledge. 
Yalova Sosyal Bilimler Dergisi

Mardin, Ş. (1973). Center Periphery Relations - A Key to Turkish Politics. Deadalus, Vol.2, No.1, pp.169-190.

Özbudun, E. (1995). Türk Anayasa Hukuku. Ankara: Yetkin Yayınları.

Park, H.J. (2006). Democratic People's Republic of North Korea, Schlager, N. ve Weisblatt, J. (Ed.). Political systems and Parties içinde (ss. 737-743). New York: Facts on File.

Roskin, M.G. (2014). Çă̆daş Devlet Sistemleri. Bahattin Seçilmişoğlu (Çev). Ankara: Adres Yayınları.

Roskin, M.G., Cord, R.L., Medeiros, J.A. ve Jones, W.S. (2012). Siyaset Bilimi. Atilla Yayla (Çev.). Ankara: Adres Yayınları.

Seddon, D. (2005). A Political and Economic Dictionary of the Middle East. London and New York: Europa Publications.

Sadowski, Y.M. (1988). Baathist Ethics and the Spirit of the State Capitalism. Chelkowski, P.J. ve Pranger, R.J. (Ed.). Ideology and Power in the Middle East içinde (ss. 160-184). Durham: Duke University Press.

Voren, R. (2009). On Dissidents and Madness - From the Soviet Union of Leonid Brezhnev to the Soviet Union of Vladimir Putin. Amsterdam - New York: Rodopi.

Zaznaev, O. (2008). The Presidentialization of a Semi-Presidential Regime: the Case of Russia. White, S. (Ed.). Politics and the Ruling Group in Putin's Russia içinde (ss. 27-41) New York: Palgrave Macmillan.

Zürcher, E.J. (2003). Turkey - A Modern History. Leiden: I.B. Tauris. 